\title{
HERMENEUTYKA I JĘZYK
}

Właściwe zadania hermeneutyki powstają wraz z wyłonieniem się sensu językowego. Jeśli problemem dla niej jest sens otaczającego człowieka świata, natura czasu i dziejowości, prawdy i złudzenia, to dzieje się tak dlatego, ponieważ hermeneutyka natrafia na swej drodze język i mowę z całą ich złożonością. Stając wobec problemu językowego, hermeneutyka czuje się w sytuacji dość kłopotliwej. Okazuje się bowiem, że nie jest tutaj sama. Do rozprawiania o języku rości sobie dzisiaj pretensje wiele nauk: językoznawstwo ogólne, szczegółowe i porównawcze, semiotyka i semantyka, logika i gramatyka, psychologia opisowa i genetyczna, fizjologia i neurologia. Język stał się dla współczesnej nauki prawdziwą ziemią obiecaną odkryć. W dążeniu do jej osiągnięcia nikt nie martwi się zbytnio o kompetencje i właściwe przedmioty badań. Naukowcy są przekonani, że czas na systematyzację przyjdzie później a obecnie jest czas twórczych hipotez i szczegółowych odkryć. Stąd miejsce hermeneutyki wśród innych nauk o języku wciąż jeszcze nie jest wyraźnie sprecyzowane. Spróbujmy jednak choć prowizorycznie je zarysować.

W którym punkcie „genezy mowy” otwierają się zadania dla hermeneutyki?

Najtrafniej wydaje się odpowiadać na to pytanie P. Ricoeur. Jego rozstrzygnięcie jest usprawiedliwione szeregiem analiz, których nie możemy tutaj bliżej omawiać. Do najbardziej kluczowych należą te, które są uzasadnieniem następującej tezy: znaki języka mają charakter int e n c jon alny. Znaki mówią o czymś i są kierowane do kogoś, mają swój przedmiot, swój podmiot i swego adresata. Jako takie podlegają rozumieniu i mogą także podlegać interpretacji. Stąd właśnie zadania hermeneutyki wyłaniają się w momencie, w którym dojdzie do tzw. „wydarzenia słownego". 
Czym jest, ,wydarzenie słowne”?

Mówiąc językiem lingwistyki, jest ono ,przejściem od kodu do przekazu”. Od czasów F. de Saussure’a utrwaliło się w językoznawstwie rozróżnienie między ,,językiem” a „mową” i paralelnie między , lingwistyką języka” a ,lingwistyką mowy”. Przez ,język” rsp. „,system języka” rozumie się, ,sumę wszystkich tych reguł, które w danej wspólnocie językowej determinują użycie dźwięków i form, jak również syntaktycznych i leksykalnych środków wyrazu. Można więc powiedzieć, że «la langues to ponadindywidualny system językowy, abstrakcja, której istnienie warunkuje wzajemne porozumiewanie się jednostek ludzkich” 1. „Język” — jak widać — niczego jeszcze nie ,mówi”, dopiero „mowa” mówi. Mowa oznacza konkretne, oparte o ,system językowy” i bezpośrednio o konkretne dyrektywy gramatyczne uży cie odpowiednich dźwięków i form. Strukturę ,,języka" wyznaczają ,elementy znaczące” i ,reguły ich użycia”. Strukturę mowy wyznacza gramatyka i układ zdań. Między instancją języka a instancją mowy pojawia się , wydarzenie słowne”. Ono to stanowi ,przejście od kodu do przekazu”.

Ricoeur wskazuje na cztery podstawowe cechy wyróżniające ,mowę" od ,języka”:

Pierwsza cecha: mowa za każdym razem spełnia się w sposób czasowy i aktualny, natomiast system językowy jest wirtualny i pozaczasowy. Emil Benvéniste nazywa 〈instancją mowy) wejście wydarzenia w system języka.

Druga cecha: o ile język nie ma podmiotu — w tym sensie, że py.* tanie (kto mówi) nie jest prawomocne na poziomie systemu językowego - mowa odsyła do tego, kto ją wypowiada za pośrednictwem złożonej gry wskaźników, którymi są zaimki osobowe; instancja mowy jest, chciałoby się rzec, samoreĩerencyjna.

Trzecia cecha: o ile w języku znaki odsyłają tylko do innych znaków, o ile więc język jest pozbawiony świata zewnętrznego, podobnie jak jest pozbawiony czasu i podmiotowości, mowa jest zawsze na jakiś temat, odsyła do jakiegoś świata, który usiłuje opisać, wyrazić, przedstawić. Funkcja symboliczna języka spełnia się właśnie w mowie.

Czwarta cecha: język jest tylko warunkiem porozumienia, któremu dostarcza swoje kody, natomiast w mowie dopiero dokonuje się wymiana przekazów; w tym sensie jedynie dla mowy istnieje świat oraz 〈drugi〉, rozmówca, do którego jest adresowana" 2.

Mowa urzeczywistnia się jako wydarzenie. Tematem hermeneutyki nie jest jednak wydarzeniowy charakter mowy. Gdyby tak było, hermeneutyka byłaby rodzajem fonologii. Mowa, urzeczywistniając się w wy-

1 B. Malmberg, Nowe drogi w językoznawstwie, Warszawa 1969, 71.

2 Wydarzenie $i$ sens $w$ mowie, tł. E. Bieńkowska, ,Teksty", 6 (1972) 105-106. 
darzeniu, zarazem przekracza czysto wydarzeniowy charakter samej siebie. Dokonuje się to dzięki znaczeniu. Mowa to system zdarzeń z n a c zą cy ch. Jak na cztery sposoby mowa realizowała się jako wydarzenie, tak na cztery sposoby ,wydarzenie przekracza siebie ku znaczeniu: poprzez utrwalenie, które wydziera je przemijaniu; poprzez rozszczepienie, które wyzwala z intencji myślowej autora; poprzez otwarcie na świat, wyrywające je $z$ ograniczeń sytuacji dialogowej; oraz poprzez uniwersalność nieskończonego audytorium" ${ }^{3}$. Tematem hermeneutyki jest ,wydarzenie mowy" o tyle, o ile zostało ono przekroczone w strone znaczenia.

Punkt widzenia hermeneutyki na mowę różni się nie tylko od punktu widzenia lingwistyki, lecz także od punktu widzenia współczesnej semiotyki i semantyki. Wprawdzie niesposób ustalić tutaj precyzyjne granice, niemniej dążności podstawowe są rzeczywiście istotnie różne. Dla semiotyki i semantyki język jest elementem składowym poznania naukowego. W badaniach nad nim chodzi ostatecznie o takie przepracowanie języka, aby mógł on służyć jako niezawodne narzędzie komunikacji naukowej. Opis teoretyczny jest tu inspirowany przez cele pozateoretyczne. Dla hermeneutyki ideą wiodącą jest czysto teoretyczny opis już zastanych znaczeń. Ostatecznie chodzi o uchwycenie rdzenia intencjonalności: „Zrozumieć tekst to iść za ruchem sensu prowadzącego od tego, co tekst mówi, do tego, o czym mówi" " . Postawa czysto teoretycznego opisu wiąże hermeneutykę z postawą filozoficzną i fenomenologiczną. Ale nie tylko postawa metodologiczna jest tu pokrewna. Także radykalny sposób stawiania pytań, próby dotarcia do korzeni znaczeń w człowieku, uchwycenia podstaw wszelkich doświadczeń rozumiejących, wyciskają na hermeneutyce piętno filozoficzne i to nawet wtedy, gdy chodzi wyłącznie o rozumienie tekstu literackiego. Niesposób jeđnak już dzisiaj precyzyjnie ustalić granice kompetencji. W gruncie rzeczy to, co nazywa się ,metodą hermeneutyczną" jest zbiorem wielu propozycji metodycznych, związanych ściśle z regionem sensu, który jest przedmiotem rozumienia.

W niniejszym wystąpieniu pragne dotknąć tylko jednego zagadnienia wiążącego się $z$ hermeneutyką mowy utrwalonej $w$ znaczeniu. Chodzi o to, co Heidegger nazywa ,siłą nazwania” słowa. Immanentną właściwością nazw jest specyficzna ,siła nazwania”, mocą której słowo przywołuje i odsłania rzecz, przedmiot, wydarzenie. Siła nazwania ma oparcie w intencjonalności. Ale intencjonalność nazwy jest, jak to wykazał Ingarden, zjawiskiem złożonym ${ }^{5}$. Składają się na nią, nie licząc całej reszty, dwa podstawowe momenty: intencjonalny wskaźnik kierunkowy i zna-

3 Art. cyt., 112.

4 Art. cyt., 115.

O dziele literackim, Warszawa 1960, 100-116. 
czenie. Dzięki pierwszemu nazwa wskazuje poza siebie na jakiś przedmiot, mówi: to, tamto, tu, tam. Wskaźnik intencjonalny może być potencjalny lub aktualny. Gdy mówimy ,,jakieś to” lub ,,jakieś tamto”, wskaźnik kierunkowy pozostaje nieokreślony, właśnie potencjalny. Gdy mówię „,to tu" lub ,tamto tam”, wskaźnik kierunkowy aktualizuje się. Z kolei drugi moment intencjonalności - znaczenie nazwy, informuje nas o tym, co jest tu, lub co jest tam. Wskazuje ono na jakąś szeroko pojętą „,treść” przedmiotu (treść materialną, formalną, sposób istnienia). „Siła nazwania" nazwy wyrasta zarówno z intencjonalności wskaźnika kierunkowego jak ze znaczenia. Jest rzeczą znamienną, że przenika ją swoista „,czasowość”. Są nazwy, które kiedyś mówiły wiele a dzisiaj nie mówią już nic. Jak do tego doszło? Jakie mechanizmy rządzą przemianami „,siły nazwania" nazw? Dlaczego choć znaczenia pewnych nazw są niezmienne, ich „siła nazwania” podlega przemianom? Jest to jedno z bardziej szczegółowych pytań hermeneutyki filolozoficznej, które interesują nie tylko filozofa języka. Podejmując je i rozwijając, współczesna filozofia języka dokonuje swoistej destrukcji mowy i zarazem swoistej afirmac ji mowy. Poświęcę obecnie kilka słów zarówno jednej jak drugiej.

\section{DESTRUKCJA MOWY}

Gdy słowo traci pierwotną ,siłę nazwania”, mówimy, że stało się „,niezrozumiałe”. Niezrozumiałość jest nie tylko faktem psychicznym, który wynika z braku odpowiednich uzdolnień, wykształcenia czy wysiłku czytelnika, to dla hermeneutyki przede wszystkim następstwo zaburzeń w sferze intencjonalności znaczeń. Znaczenia przestają nas odsyłać do tego świata, który jest światem naszego otoczenia, lecz wskazują na świat nam obcy. Kryzys „siły nazwania” to znak, że jakiś ,,świat otoczenia" uległ rozpadowi. Aby przywrócić słowu jego pierwotną siłę, nie wystarczy odbudować znaczenie tej jednej nazwy, lecz trzeba ożywić cały świat otoczenia. Bo słowo nie przemawia w osamotnieniu, lecz w kontekście pewnego świata. Trzeba, jak mówi G. W. Gadamer, doprowadzic do „zmieszania się horyzontów” świata: tego, w którym my przytomnie bytujemy, $z$ tym, w którym bytuje autor niezrozumiałego dla nas słowa i samo słowo. A to nie jest łatwe.

Osłabienie ,siły nazwania” niektórych słów nie może jednak podlegać jednostronnej ocenie. Rzecz w tym, że pewne słowa wykruszają się dlatego, że się powinny wykruszyć. Inne z kolei wykruszają się z tej racji, że w człowieku coś się zachwiało, coś autentycznie ludzkiego zamarło. Są światy słów, których odbudować już nie można, są jednak i takie, które odbudować trzeba, jeśli człowiekowi ma być przywrócone jego człowieczeństwo. Heidegger, który w filozoficznej destrukcji „mowy upadłej” 
idzie dzisiaj bez wątpienia najdalej, wskazuje, że źródłem upadku mowy jest upadek człowieka w nieautentyczność. Człowiek nie „mówi”, to, co robi, gdy mu się wydaje, że mówi „mówi”, jest „,paplaniną”, która sprawia krzyk. Człowiek zerwał pierwotny kontakt z bytowaniem. Uciekając od samego siebie człowiek zagłusza swą „codzienną paplaniną" wielkiə „milczenie sumienia”, które domaga się odwrotu. Sumienie mówi przez swe milczenie, które jest słyszalne, jak słyszalną jest cisza, gdy ustają hałasy. Jego głos wzywa do jednego: by człowiek w ogóle „chciał mieć sumienie" 6. Tak więc destrukcja pewnego typu mowy jest dla Heideggera koniecznym krokiem na drodze powrotu do ,,pierwotnej prawdy bytowania" i do uczulenia na jej wymowę.

Heideggerowska krytyka „mowy upadłej” wymaga szczególnie wnikliwych rozważań, których jednak tutaj nie jesteśmy w stanie przeprowadzić. Można się z tą krytyką zgadzać lub nie, ale nie można nie brać jej pod uwagę. Przykuwa ona spojrzenie z wielu powodów. Najpierw z racji radykalizmu historycznego: dotyka bowiem całej tradycji filozoficznej od Platona i Arystotelesa do naszych czasów. Po wtóre z racji radykalizmu antropologicznego: łączy bowiem upadek mowy z ontologicznym upadkiem człowieka. I wreszcie z racji radykalizmu ogólnofilozoficznego: krytyka mowy jest zarazem krytyką świata otaczającego wspóxczesnego człowieka.

Heidegger analizuje wiele przykładów. Zatrzymam się przy jednym, bodaj najbardziej podstawowym.

Zwraca on uwagę na znamienną ewolucję, jakiej z biegiem wieków podlegało na gruncie zachodniej kultury słówko ,,jest”. Znaczenie tego słówka odbija w syntetycznym skrócie aktualnie wiążący go sposób bytowania człowieka w świecie otaczającym. Człowiek żyje przede wszystkim w pośrodku tego, co dla nịego „,naprawdę jest”. Dla Platona i platonizmu tym, co „jest naprawdę”, były pozaświatowe idee, zaś świat o tyle, o ile uczestniczył w ich bycie. Dla Arystotelesa ,naprawdę jest” ukryta poza przypadłościami bytu ich niezmienna substancja. Dla Kartezjusza i idealizmu subiektywnego liczyła się przede wszystkim świadomość w postaci „ego cogito”. Z kolei dla Hume'a sens rzeczywistości pierwotnej pokrywa się z faktem impresji, które odbieramy tu i teraz. Wpływ Hume'a i pozytywizmu zdaje się ciążyć w sposób przemożny na współczesnym człowieku. W życiu codziennym człowiek używa słówka „jest” w tak rozmaitych kontekstach, iż budzi to podejrzenie, że słówko to zostało pozbawione głębszego sensu. Mówimy: „Bóg jest”, ,jest samochód”, „w sali jest wykład”, „na szczycie góry jest cisza”. Heidegger cytuje słowa Nietzschego: znaczenie słówka ,,jest" to „ostatni oddech

6 M. Heidegger, Sein und Zeit, Tübingen 1967, § 55-57. 
rzeczywistości, która wyparowała". Losy znaczeniowe słówka odbijaja proces odchodzenia człowieka od ,prawdy bytowania”. W świadomości współczesnej jego znaczenie obraca się wokół tego, co jest „trwale obecne", konkretniej... wokół trzeciej osoby liczby pojedynczej czasu teraźniejszєgo strony aktywnej: ,to jest”, ,on jest”. Coś dla nas jest wtedy, gdy działa na nas w naszej teraźniejszości i gdy możemy temu działaniu przeciwstawić nasze działanie. Naprawdę istnieje dla nas to, co tu i teraz jest naszym przedmiotem, co stojąc naprzeciw nas, najgłośniej do nas i o nas „krzyczy" ?.

Podobną ewolucję przechodzą inne, podstawowe słowa naszego języka: substancja, logiczność, rozumność, fizyczność, istota itp. Podstawowym rysem tej ,ewolucji w stronę upadku” jest oderwanie sensu słów od czasu, w którym stopniowo objawia się człowiekowi ,prawda bytowania". Wizja czasu jest tu zbieżna $z$ wizją, jaką kiedyś mieli prorocy biblijni i św. Paweł: czas to wymiar, w którym dopełnia się objawienie. Prawda dla Heiddegera nie istnieje w sferze pozbawionej czasu, jak u Platona. Ona pojawia się w czasie a wskazuje na wieczność. A wieczność i bezczasowość to nie to samo. Drogą do bezczasowości jest negacja czasu, drogą do wieczności jest stopriowe dojrzewanie w czasie. W kontekście poglądów na naturę czasu należy umieścić krytykę, jaką Heidegger kieruje pod adresem Arystotelesa za jego koncepcję wiedzy opartej o definicje pojęć. Definicja wprowadza w proces odsłaniania się prawdy element stałości, bezruchu. „Siła definiowania” przeciwstawia się „,sile nazywania". Tam, gdzie mamy tendencje do stopniowego odsłaniania się i obowiązek oczekiwania na pełnię odsłonięcia, definicja wprowadza złudzenie kresu. W procesie płynącego czasu definicja absolutyzuje jeden z momentów. W imię czego dokonuje tej absolutyzacji? Heidegger odpowiada: w ostatecznym rozrachunku w imię panowania. U podstaw znaczenia, jaką przyznawano w nauce definicji od czasu Arystotelesa, legła „,wola mocy”. Heidegger nie twierdzi, jakoby wszystkie definicje były fałszywe. One są tylko prowizoryczne. Możemy poprawnie zdefiniować takie przedmioty jak dom, piec, mur i cegłę, z której piec, mur i dom są zrobione. Każda $z$ definicji odsłoni jakąś prawdę nie tylko o danym przedmiocie, ale pośrednio o ziemi, która istnieje i jest podatna dla technicznej modelacji. Ale nie powie wszystkiego. Zaś prawdy cząstkowe, które zaproponuje, będą służyć raczej naszemu działaniu w świecie niż naszemu poznaniu istnienia ${ }^{8}$.

Heideggerowska „destrukcja mowy” ma oczywiście głębszy sens, nì li tylko językowy. Jest ona częścią krytyki, jaką wysuwa on pod adre-

7 M. Heidegger, Einführung in die Metaphysik, Tübingen 1967, 67-70.

8 Por.: W. Anz, Die Stellung der Sprache bei Heidegger, w: Heidegger, herausg. von O. Pöggeler, Köln-Berlin 1970, 311. 
sem europejskiego racjonalizmu. Nie jest to krytyka odosobniona. Hei-degger stoi $\mathrm{w}$ jednym szeregu $\mathrm{z}$ takimi myślicielami jak $\mathrm{H}$. Bergson, M. Scheler, E. Husserl, K. Jaspers i inni, wśród których spotykamy także przedstawicieli nauk szczegółowych. Aby ożywić w słowie jego pierwotną ,siłę nazwania”, rezygnuje zupełnie z języka, którym zwykła się posługiwać współczesna nauka i współczesna filozofia. Sięga do języka sztuki, religii, do filozofii przedsokratejskiej, do poezji Hölderlina i Rilkego, w której mowa poddaje się władaniu życia a rezygnuje z panowania nad kimkolwiek i czymkolwiek. Nie należy tego uważać za zwrot w stronę irracjonalizmu. Jesteśmy raczej świadkami narodzin nowej, pogłębionej wersji ,racjonalizmu”, bliższej ideałowi mądrości niż ideałowi dominacji. Zwrot do języka sztuki jest wyrazem utajonego przeświadczenia, że rolę wiodącą w naszym poznaniu i rozumieniu świata odgrywają wartości, którym sztuka na swój sposób daje wyraz. Tylko ten, kto otwarł się na wartości, otwarł się zarazem na ciszę, w której mówi swym wielkim milczeniem ,,prawda bytowania”.

\section{AFIRIMACJA MOWY}

O ile analizy Heideggera mogą służyć jako przykład destrukcji mowy z powodu próżni znaczenia, o tyle badania Ricoeura są przykładem afirmacji pewnego szczególnego rodzaju mowy z powodu pełni, którą przywołuje. Chodzi o mowę s y m b ol u. Wybór symbolu nie jest tutaj dziełem przypadku. W filozofii już od początków XIX wieku a nawet wcześniej narastało zainteresowanie mitami, które nie są niczym innym jak rozbudowaną mową symbolu. Późniejsze badania fenomenologów religii ustaliły, że język religijny jest w swym rdzeniu językiem typu symbolicznego. Ze swej strony Ricoeur odkrywa, że takim samym językiem są zapisane wielkie teksty literackie, leżące u podstaw naszej kultury: mity sumero-akadyjskie, judeo-chrześcijańskie, mity greckie. Człowiek snuje w nich opowieść o tajemnicy zła: opowiada, skąd się zło wzięło, na czym polega i jak można się od niego wybawić. Ricoeur jako filozof interesuje się stosunkiem między tym, co w człowieku jest poddane jego woli, a tym, co w nim jest poza jej zasięgiem, aby w ten sposób uchwycić „ludzki wymiar wolności”. Granicę wolności człowieka wytycza świadomość jego winy: człowiek nie czyni dobra, które chce czynić, a czyni zło, którego nie chce. Stąd świadomość winy. Wina to ludzki sposób przejawiania się zła. Stąd u Ricoeura zainteresowanie ,symboliczną mową mitu", w której człowiek chce opisać tajemnicę swego zła, swej winy.

Styl myślenia Ricoeura można określić krótko: jest to myślenie wyłaniające się ,z wnętrza symbolu”. Zrozumieć mowę symbolu znaczy uchwycić to, o czym mit mówi, co mit mówi, do kogo mówi i jak przed- 
stawia się to szczególne roszczenie do prawdy, jakie mit zawiera. Wychodząc od mitu jako rozbudowanego symbolu, chce Ricoeur pojąć, na czym polega symboliczna funkcja mowy. Ricoeur daleki jest od sceptycyzmu i scjentyzmu, które utożsamiają mit z baśnią i przeciwstawiają jego mowie precyzyjny, zdawałoby się, język nauk zmatematyzowanych. Punktem wyjścia rozumienia mitu musi być akceptacja mowy mitu. Ricoeur pisze: „Podejmujemy tu drogę twórczej interpretacji sensu, wier-nej zarazem donacji sensu przez symbol, jak zobowiązaniu filozofii, które znaczy 'rozumieć' " 9. Aby rozumieć, trzeba uwierzyć, aby uwierzyć, trzeba rozumieć. Spirala hermeneutyczna u Ricoeura obejmuje sam rdzeń postawy hermeneutycznej. Dzięki niej możemy uzyskać najgłębsze usprawiedliwienie „mowy mitu”. Język symboliczny odzyskuje pierwotną ,,siłę nazwania". Prawdą mitu jest bowiem przede wszystkim to, że otwiera on przed człowiekiem jakiś inny świat, świat, który jest zarazem w nim jak poza nim, a który bez „mowy symbolu” byłby dla niego niedostępny.

Tak więc jądrem badań Ricoeura są badania nad naturą symbolu. Są to badania podwójnie ważne: raz, bo są usprawiedliwieniem języka z punktu widzenia jego ,siły nazwania”, drugi raz, bo usprawiedliwia-ją „,mowę religii”, która przez pozytywistyczny wzorzec mowy została wyeliminowana ze sfery komunikacji.

Ricoeur precyzuje bliżej, co rozumie przez słowo „symbol”. Symbol nie jest dla niego tym samym, co ,znak”, i nie jest tym samym, co ,,metafora".

Sądzi on, że wprawdzie każdy symbol jest znakiem, to jednak nie każdy znak jest symbolem. Symbol wiąże ze znakiem cecha intencjonalności: w jednym i drugim przypadku wskaźnik kierunkowy znaczenia przenosi nas w świat, który leży na zewnątrz znaku. Znak i symbol mówią coś o świecie, człowieku, jego dziejach, tajemnicach, o tym, co jest poza światem. Ale symbol, w przeciwieństwie do znaku, mówi jeszcze coś więcej. Symbole mają co najmniej podwójny wskaźnik kierunkowy. Jeden promień dotyka zjawiska, które jest zmysłowo dane luh co najmniej może być zmysłowo, bezpośrednio odczute. Drugi promień zdąża w kierunku czegoś, co nie jest i nie może być bezpośrednio dane. Jest to zatem wskaźnik potencjalny. Między tym, co aktualnie dane, a tym, co potencjalnie wskazane, zachodzi jednak jakaś więź podobieństwa, mniejsza lub większa analogia. $\mathrm{Na}$ mocy analogii materiał dany bezpośrednio dookreśla nam bliżej to, co nie jest i nie może być dane bezpośrednio. Mówimy np.: wina jest jak ,plama”, człowiek winny, to człowiek ,,splamiony”. Plama leży w polu naszych spostrzeżeń. Wina jest wprawdzie odczuwalna, ale niejasno i niewyraźnie, jest tajemnicza. Na-

\footnotetext{
9 Finitude et culpablitité, t. II: La symbolique du mal, Paris 1960, 324.
} 
dając wyobrażeniu plamy symboliczny charakter i opierając się na niejasnym wyczuciu pewnej analogii, otwieramy się na głębsze zrozumienie tajemnicy winy. Mówimy: to jest plama, ale nie zwyczajna plama, to plama, która ,plami duszę”. Podobnie jest z symbolem ,ojca” na określenie Boga, „Adama” na określenie ,natury” człowieka w pierwotnym doświadczeniu winy, ze słowem, „miłość” przeniesionym ze stosunków międzyludzkich w sferę stosunków transcendentnych.

Mowa symbolu zaczyna się tam, gdzie kończą się możliwości języka jednoznacznego. A możliwości te kończą się wtedy, gdy słowu brakuja wyraźnych doświadczeń i zachodzi konieczność poszerzenia znaczenia słów o nowy wymiar. Doświadczenia zmysłowe stają się punktem wyjścia do uchwycenia nowych, często radykalnie innych wymiarów rzeczywistości. W tym momencie ,siła nazwania" słowa wcale nie maleje, przeciwnie ona wzrasta, pogłębia się, słowo znaczy wtedy więcej niż znaczy normalnie.

Tym też różni się symbol od metafory. Metafora jest także znakiem wieloznaczącym. Wprawdzie ona także ustala i odkrywa pewne analogie, ale wszystkie człony owych analogii są lub mogą być jednakowo bezpośrednio dane w doświadczeniu. Gdy symbol jest przejściem z jednego świata do drugiego, metafora operuje zasadniczo w jednym i tym samyrn świecie. „Widzę ludzi, jako drzewa chodzących”. Zarówno drzewo jak. człowiek są dane w polu tego samego doświadczenia zewnętrznego ${ }^{10}$.

Wyniki badań Ricoeura nad wielką mitologią ludzkości streszcza formuła, która w sposób dobitny uwypukla ,siłę nazwania” symbolu. Brzmi ona: ,symbol daje do myślenia”. „Sentencja, która mnie zachwyca, pisze Ricoeur, mówi dwie rzeczy: symbol daje; to, co daje, jest do myślenia, jest o czym myślenia... Aforyzm sugeruje, że wszystko jest już zagadkowo dane a jednak wszystko trzeba zaczynać i rozpoczynać w wymiarze myślenia..." I dalej: „W każdym bowiem razie coś zostało zagubione, nieodwołalnie zagubione: bezpośredniość wierzenia. Jeżeli jednak nie jesteśmy w stanie żyć wielkkimi symbolami Sacrum według pierwotnego wierzenia, możemy, my ludzie współcześni, zdążać poprzez i w oparciı ג o krytykę w stronę wtórnej naiwności. Krótko: interpretując, możemy znów od nowa usłyszeć; w ten sposób dzięki hermeneutyce rozwija się

10 Por. dz. cyt., 1-25. Oczywiście zaproponowana analiza istoty symbolu nie wyczerpuje zagadnienia. We współczesnej filozofii używa się tego pojęcia w sensie diametralnie przeciwnym do tego, jakim operuje np. Ricoeur. W tym drugim znaczeniu „symbol" to tylko wskaźnik na coś, co niewiadome, co może być ,takie lub inne". W tym znaczeniu mówi się np. o ,symbolach logicznych", jak znaki ,, ${ }^{\prime \prime},$, ,y", ,z", które ,symbolizują" dowolne zdania. Stąd gdy jedni mówią: "to t y lko symbol”, inni - jak Ricoeur - wolą powiedzieć: „to a ż symbol". Spór o naturę symbolu jest odbiciem sporu między nominalizmem a różnymi odmianami ,realizmu” pojętego jako stanowisko w kwestii ,powszechników”. Stanowisko Ricoeura i fenomenologórv jest w tym przypadku zdecydowanie antynominalistyczne. 
zarazem donacja sensu przez symbol jak rozumiejąca czynność rozszyirowania" 11.

Mitologia genezy zła i mitologia ostatecznego wyzwolenia się spod zła układa się w oczach Ricoeura w cztery podstawowe grupy: mit sumero-akadyjski, judeo-chrześcijański, mit prometejski i platoński mit „,duszy wygnanej”. W każdym z nich natrafiamy na inną, symbolicznie przedstawiona, koncepcję zła i wyzwolenia się spod zła. Korelatywnie inną jest wizja Boga i idea podstawowej ,prawdy" człowieka. Mit sumero-akadyjski odsłania zło jako równoznaczne $z$ odwiecznym chaosem a dobro jako równoznaczne z porządkiem w ogóle. Wyzwolenie spod zła polegać będzie na poddaniu się człowieka ustalonemu porządkowi: kosmicznemu, społeczno-religijnemu. Symbolika judeo-chrześcijańska jest wyraźnie obrazoburcza w stosunku do wizji sumero-akadyjskiej. Nie ma odwiecznego chaosu, świat został stworzony $\mathrm{z}$ niczego, wszystko, co jest, jest dobre. Zło bierze się z buntu człowieka. Nowa symbolika przynosi w zarodku nową wizję człowieka: człowiek to istota zdolna do dokonywania wyborów. Wyzwolenie spod zła polega na wolnym poddaniu się prawu miłości, którego jako pierwszy w pełni dokonał Chrystus „drugi Adam”. Nowa idea zbawienia wiąże się z nową wizją bóstwa, symbolizowaną słowami: „Ojciec”, „Miłość”. Sens pierworodnego upadku odsłania nadzieja, którą wyraża św. Paweł: — „o ileż bardziej obfitować będzie sprawiedliwość..." Mity greckie z kolei rodzą się na uboczu symboliki judeo-chrześcijańskiej, bez związków polemicznych. Mit prometejski upatruje naturę zła w ,fatum”, któremu podlegają zarówno ludzie jak bogowie. Droga wybawienia spod fatum wiedzie poprzez sztukę. Człowiek kontemplując wzniosłość i wspaniałość własnego dramatu podyktowanego przez fatum, uzyskuje dystans w stosunku do niego, sam staje się heroiczny i w ten sposób w postawie estetycznej uzyskuje namiastkę zbawienia. Mit ,duszy wygnanej” identyfikuje zło z ciałem a dobro z duchem. Dusza została wtrącona w ciało za karę. Po śmierci powróci do świata ducha. Droga zbawienia jest drogą wyzwolenia się $\mathrm{z}$ ciała.

$\mathrm{Na}$ gruncie judeo-chrześcijańskim symbolika winy wcale nie jest jednolita. Systematyzując i porównując pojawiające się tutaj symbole i ich zespoły, Ricoeur ukazuje proces powolnego ,interioryzowania się" poczucia winy w człowieku. Od ujęć czysto zewnętrznych, w któryci przeważała symbolika plamy i nieczystości (brudu), dochodzimy do ujęć coraz bardziej „,wewnętrznych" (wygnanie, błądzenie, ciężar, tęsknotai, wśród których podstawowym okazuje się symbol „odrzuconej miłości”. wina jest jak ,odrzucona, wzgardzona miłość”.

11 Dz. cyt., $324-325$. 
Bezpośrednim odkryciem Ricoeura jet odkrycie ,życia symboli”. Świat symboli jest światem „wewnętrznie żywym”, rozwijającym się, w którym coś zanika i coś powstaje. Stosunek symbolu, który przestaje przemawiać, do symbolu, który wchodzi na jego miejsce, jest stosunkiem dialektycznym. Najpierw wydaje się, że nowy symbol cały wyczerpuje się w kwestionowaniu. Gdy w miejsce ,plamy" wchodzi „wygnanie”, tym, co przede wszystkim uderza, jest „obrazoburczy” charakter nowego. Nowość wywołuje zgorszenie. Przy bliższym wejrzeniu okazuje się jednak, że nowe słowo podejmuje jakąś intuicję starego słowa i tym samym zachowana zostaje ciągłość ewolucji. Dzieje symbolu to dzieje coraz to głębszego dookreślania się potencjalnych intencji symbolu z jednoczesnym opróżnianiem się niektórych już uprzednio określonych treści. Ruch symbolu idzie zarówno w stronę przyszłości, jak przeszłości. Każdy symbol wyznacza generalny kierunek przyszłej symboliki, pewne symbole pozytywnie umożliwia, inne wyklucza. Symbol działa jednak także wstecz. Gdy św. Paweł nazwał Chrystusa „drugim Adamem”, to jego odkrycie zmieniło potencjalny sens symbolu „,pierwszego Adama”. Tak więc czas jest immanentną właściwością symbolu. Sprawia on zarówno wewnętrzny ruch znaczenia jak jego trwającą identyczność.

Empiryczną podstawę symboli stanowi materiał doświadczeniowy. Często jest on brany po prostu z wyobraźni. Tak jest w micie sumeroakadyjskim, tak w mitach greckich. Nieco inaczej jest w symbolice judeochrześcijańskiej. Tutaj zazwyczaj wydarzenie poprzedza symbol, a nie symbol poprzedza wydarzenie. Trzon tej symboliki powstaje $\mathrm{w}$ ten sposób, że realnym faktom dziejów nadaje się głębsze, to znaczy symboliczne znaczenie.

Analizy Ricoeura narzucają wiele doniosłych wniosków ${ }^{12}$. Dwa z nich wydają mi się najbardziej ważne, chociaż Ricoeur wprost ich nie formułuje. Obydwa dotyczą interesującej nas sprawy „,siły nazwowej” nazw. Należy, po pierwsze, przyjąć, że istnieje jakieś pierwotne doświadczenie ,symbolicznego wymiaru” świata, które jest wyrażane w konkretnych symbolikach religijnych, poetyckich czy filozoficznych. Leży ono u źródeł aktu językowego, w wyniku którego mowa jednoznaczna, przywiązana do ziemi i jej spraw powszednich, staje się mową o tym, co inne niż ziemia i niepodobne do spraw powszednich. Należy także, po wtóre, przypuścić, że źródłem symbolicznej funkcji języka jest aksjologiczne doświadczenie Sacrum. Znaczyłoby to, że także w tym przypadku prymat doświadczeń aksjologicznych jest niemożliwy do podważenia.

12 Wiele cennych refleksji na ten temat znajdujemy w innej pracy Ricoeura: Le conflit des interprétations. Essais d'herméneutique, Paris 1969. Por. J. Tischner, Perspektywy hermeneutyki, ,Znak”, 200-201 (1971) 145-172. 


\section{TEOLOGIA A „SIEA NAZWANIA” SEOW}

Hermeneutyka filozoficzna nie chce i nie może zastępować innych hermeneutyk, w tym także hermeneutyki teologicznej. Zdaje ona sobie sprawe z tego, że dla innych hermeneutyk może ona najczęściej nie być niczym więcej, jak generalnym tłem, które należy widzieć, chociaż nie musi się z niego niczego czerpać. Gdy jednak powstanie problem, co dla innej, np. teologicznej hermeneutyki można ewentualnie wziąć z tego tła, nie jest jej obojętne, z których fragmentów tła będzie się korzystać. Przed operacją czerpania chciałaby ona przypomnieć krótko, co uważa za najważniejsze.

Za najważniejszą i najbardziej podstawową trzeba uznać przemianę w pojmowaniu tego, co racjonalne. Pojęcie racjonalności ulegało w ciągu wieków wielorakim przemianom. Odbijało się to nie tylko na generalnych koncepcjach nauk szczegółowych, lecz także na koncepcji teologii, która również chciała być nauką. Sens współczesnych przemian tego pojęcia polega na wyzwalaniu się spod presji ideału zaksjomatyzowanych systemów dedukcyjnych a poddaniu się ideałowi opartemu o ,próbę” doświadczenia tego, co dla człowieka pierwotne i podstawowe. Można powiedzieć, że wzorzec rozumności jest wypierany przez wzorzec mądrości, racjonalizm polegający na trafnym doborze środków do celu przez - jak zaznaczyłem - jakąś odmianę ,,sapientyzmu”, której istotę stanowi właściwe wartościowanie samych celów. Filozof nie zamierza dokonywać wyboru za teologa. Niemniej interesuje go, za którym wzorem ,racjonalizmu” opowie się nie tyle w teorii, ile w praktyce.

Gdy idzie o stosunek teologa do wyników hermeneutyki symbolu, klucz problemu daje się ująć w następujących pytaniach: co teologia zechce uczynic z językiem symbolu?? Najpierw: czy teologia jako nauka sama zechce operować innym i tylko innym niż symboliczny językiem? Czy może uzna, że także jej podstawowe pojęcia są symbolami, tj. pojęciami znaczącymi analogicznie? Jeśli uzna, że jej los jako nauki leży w związaniu się z językiem jednoznacznym, podobnym do języka nauk szczegółowych, powstaje pytanie, jaki będzie jej stosunek do symbolicznego języka religii? Czy będzie ona chciała ,tłumaczyć” to, co ów język mówi, na język jednoznaczny, kwestionując symbol w samym jego korzeniu? Czy może zechce być tylko ,,językiem o języku”, czymś w rodzaju ,metajęzyka religii"? Jeżeli zaś teologia uzna, że także jej język jest w swym rdzeniu językiem symbolicznym, będzie to miało doniosłe znaczenie dla koncepcji jej ,naukowości”. Semantyka teologii będzie wtedy semantyką innego rzędu niż semantyka nauk szczegółowych. Ale 
wtedy też między nią a hermeneutyką symbolu powstanie zgoda co do prawdy podstawowej, ,że wszystko jest już zagadkowo dane a jednak wszystko trzeba zaczynać i rozpoczynać w wymiarze myślenia", bo tylko na tej drodze można przywrócić słowu jego pierwotną „siłę nazwania". 